Karen A. Brown MD FRCPC, Bruno Bissonnette MD FRCPC, Maureen MacDonald ART, Annette O. Poon MD FRCPC

\section{Hyperkalaemia during massive blood trans- fusion in paediatric craniofacial surgery}

alors que la kaliémie intra-opératoire demeurait stable chez les enfants non transfusés d' un groupe contrôle. Lors des reconstructions, tous les enfants avaient été transfusés avec des culots globulaires récoltés en moyenne $16,1 \pm 8,4$ jours auparavant. Nous avons mesuré la concentration plasmatique de potassium de 28 culots globulaires el avons trouvé qu' elle érait inférieure à $20 \mathrm{mmol} \cdot L^{-1}$ dans les culots récoltés moins d' une semaine plus tôt et de plus de $40 \mathrm{mmol} \cdot \mathrm{L}^{-1}$ dans ceur de deux semaines et plus. Nous avons ainsi pu estimer que les enfants avaiemt reçu entre 0,2 et $1.6 \mathrm{mmol} \cdot \mathrm{kg}^{-1}$ de potassium. Les culots globulaires contiennent donc une quantité appréciable de potassium. susceptible d'amener de l'hyperkatiémie lors de transfusions massives.

Hyperkalaemia is a recognized complication of massive blood transfusion with whole blood. Both the quantity of blood transfused and the rate of blood transfusion have been identified as risk factors. ${ }^{1-4}$

Since the introduction of blood component therapy in the 1970's, all whole blood donations are separated into specific cellular and plasma components for storage. Therefore blood loss during surgery requires transfusion of each blood component. Massive transfusion with red blood cell concentrates (RBCconc) is not believed to carry the same risk of hyperkalaemia as does transfusion with whole blood because the amount of extracellular potassium per unit of RBCconc is believed to be small. ${ }^{3,5}$ However, the plasma $\left[\mathrm{K}^{+}\right]$in units of RBCconc has been measured to be in excess of $30 \mathrm{mmol} \cdot \mathrm{L}^{-1}$, and thus the extracellular mass of potassium in a unit of RBCconc may be of clinical importance even though the plasma volume in the unit is small. ${ }^{6-8}$

Our hypothesis was that massive blood transfusion with RBCconc presented a clinically important potassium load. Children undergoing major craniofacial surgery may require blood transfusion in excess of one blood volume. In addition some of these children have been observed to have high intraoperative plasma $\left[\mathrm{K}^{+}\right]$. Therefore children undergoing major craniofacial surgery (MCFS) were the focus of our investigation. The study is presented in two parts. The first is a retrospective chart 
review. The second is an analysis of the amount of potassium contained in units of RBCconc.

\section{Methods}

The following study was undertaken with Institutional Approval.

\section{Criteria for patient selection}

CONTROL GROUP

In order to document the normal variability in plasma $\left[\mathrm{K}^{+}\right]$during surgery the charts of ten patients who had undergone surgical procedures which did not require blood transfusion were reviewed retrospectively. Each patient had had at least four arterial blood samples drawn for plasma $\left[\mathrm{K}^{+}\right]$at hourly intervals.

\section{MAJOR CRANIOFACIAL SURGERY GROUP (MCFS)}

Records of 30 children undergoing MCFS between January 1987 and March 1988 were reviewed. Inclusion criteria were: (1) an intraoperative sampling frequency of once per hour, (2) a minimum of five recorded samples and (3) intraoperative blood transfusion of at least one blood volume. Cardiac arrest was considered an exclusion criterion.

The plasma $\left[\mathrm{K}^{+}\right], \mathrm{Hct}$, urine output and the hourly rate of blood transfusion were recorded from the chart. The age in days of the transfused blood was traced through the blood bank records. The free potassium load was assumed to reside only in the plasma volume of the unit of $R B C$ conc (plasma Kmass ${ }_{R B C \text { conc }}$ ) such that:

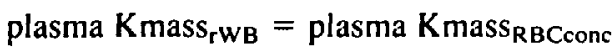

where rWB refers to the unit of reconstituted whole blood and plasma Kmass $\mathrm{KWB}_{\mathrm{B}}$ was the amount of extracellular potassium in the unit of rWB. The age-matched units of RBCconc, described in detail below, were grouped according to age by week and the mean plasma Kmass $_{\mathrm{RBC}} \mathrm{Cone}_{\mathrm{c}}$ calculated as the product of the plasma volume and the plasma $\left[\mathrm{K}^{+}\right]$. The dose of potassium ( $\mathrm{K}_{\text {dose }}$ ), expressed as $\mathrm{mmol} \cdot \mathrm{kg}^{-1} \mathrm{hr}^{-1}$, was estimated as the product of Kmass $\mathrm{rWB}_{\mathrm{r}}$ and the transfusion rate of rWB $\left(\mathrm{TR}_{\mathrm{rWB}}\right)$ :

$\mathrm{K}_{\text {dose }}=\frac{\text { plasma } \mathrm{Kmass}_{\mathrm{RBCconc}}}{\mathrm{V}_{\mathrm{rWB}}} \times \mathrm{TR}_{\mathrm{rWB}}$

where $V_{r W B}$ is the total volume of the unit of rWB.

Twenty-eight units of RBCconc of similar ages to those which had been transfused in the chart review were analyzed. The total volume per unit $\left(\mathrm{V}_{\mathrm{RBC}} \mathrm{conc}\right)$ was determined by weight (Electronic Toploader Scale, L2200P, Sartorius Laboratory). The haematocrit
(Hct RBCconc ) was determined from a well mixed $2 \mathrm{ml}$ sample (Coulter Counter Model S-Plus IV, Coulter Electronics). The plasma $\left[\mathrm{K}^{+}\right]\left(\mathrm{K}_{\mathrm{RBC}}\right.$ conc $)$ of a $1 \mathrm{ml}$ sample was measured by flame photometry (Instrumentation Laboratory, 943 Automatic Flame Photometer). Calculated variables were derived as follows:

1 Plasma Volume $\left(\mathrm{PV}_{\mathrm{RBCconc}}\right)=\left(1-\mathrm{Hct}_{\mathrm{RBCconc}}\right) \times$ $V_{\text {RBCconc }}$

2 Plasma Kmass RBCconc $=\mathrm{PV}_{\mathrm{RBC} \text { conc }} \times \mathrm{K}_{\mathrm{RBC} \text { conc }}$ where $K_{R B C c o n c}$ was the plasma $[K]$ in the unit of RBCconc.

Patient arterial blood samples had been analyzed for plasma $\left[\mathrm{K}^{+}\right]$and $\mathrm{Hct}$ (Nova Biomedical Stat Profile 4 Analyzer). The Nova Biomedical Stat Profile 4 Analyzer measured $\left[\mathrm{K}^{+}\right]$with an ion selective electrode. Within the analytical range, the assay performance had a coefficient of variation of two per cent. Hct was measured by an impedance electrode. The plasma $\left[\mathrm{K}^{+}\right]$in the units of RBCconc was analyzed by flame photometry (Instrumentation Laboratory, 943 Automatic Flame Photometer). The assay was accurate to within two per cent of the expected values using recovery experiments up to a plasma $\left[\mathrm{K}^{+}\right]$of $80 \mathrm{mmol} \cdot \mathrm{L}^{-1}$. Longitudinal plots of plasma $\left[\mathrm{K}^{+}\right]$and $\mathrm{Hct}$ were constructed for each patient. Intrapatient variability in plasma $\left[\mathrm{K}^{+}\right]$was expressed as a mean, range $\left(\Delta\left[\mathrm{K}^{+}\right]\right)$and a coefficient of variation for each patient.

Group means $( \pm$ SD) for the control and MCFS groups were calculated for: (1) the mean $\left[\mathrm{K}^{+}\right],(2)$ the range $(\Delta$ $\left[\mathrm{K}^{+}\right]$) and (3) the coefficient of variation. Differences between the control and MCFS groups were assessed with an unpaired $t$ test. A level of statistical significance of $P<$ 0.05 was accepted. In the MCFS group, within group differences in plasma $\left[\mathrm{K}^{+}\right]$over time were assessed by analysis of variance for repeated measures. ${ }^{9}$

\section{Results}

\section{Control group}

Table I shows demographic data for patients in the control group, whose ages ranged from $2-11$ yr $(12-37 \mathrm{~kg})$. The mean intraoperative plasma $\left[\mathrm{K}^{+}\right]$for this group was $3.9 \pm$ $0.5 \mathrm{mmol} \cdot \mathrm{L}^{-1}$. The mean $\Delta\left[\mathrm{K}^{+}\right]$was $0.6 \pm 0.3 \mathrm{mmol}$. $\mathrm{L}^{-1}$. The mean coefficient of variation was $5.3 \pm 1.5$ per cent.

\section{MCFS group}

Of the 30 MCFS charts reviewed, 11 met the inclusion criteria. These data appear in Table II. The MCFS group mean intraoperative plasma $\left[\mathrm{K}^{+}\right]$was $4.3 \pm 0.5 \mathrm{mmol}$. $\mathrm{L}^{-1}$, a value which was not statistically different from that of the control group. The mean $\Delta\left[\mathrm{K}^{+}\right]$was $1.8 \pm 0.6$ $\mathrm{mmol} \cdot \mathrm{L}^{-1}$. Five patients had a plasma $\left[\mathrm{K}^{+}\right]$which 


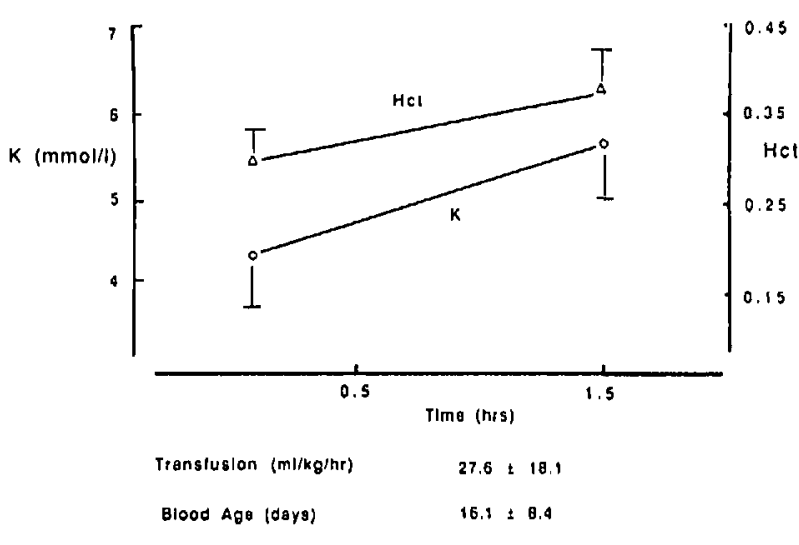

FIGURE I Figure I summarizes the mean increment in plasma $\left[\mathrm{K}^{+}\right]$ and $\mathrm{Hct}$ for the ten patients, excluding patient \# 11 , in whom an acute increase in plasma $\left[\mathrm{K}^{+}\right]$was observed. Data were expressed as mean $( \pm S D)$.

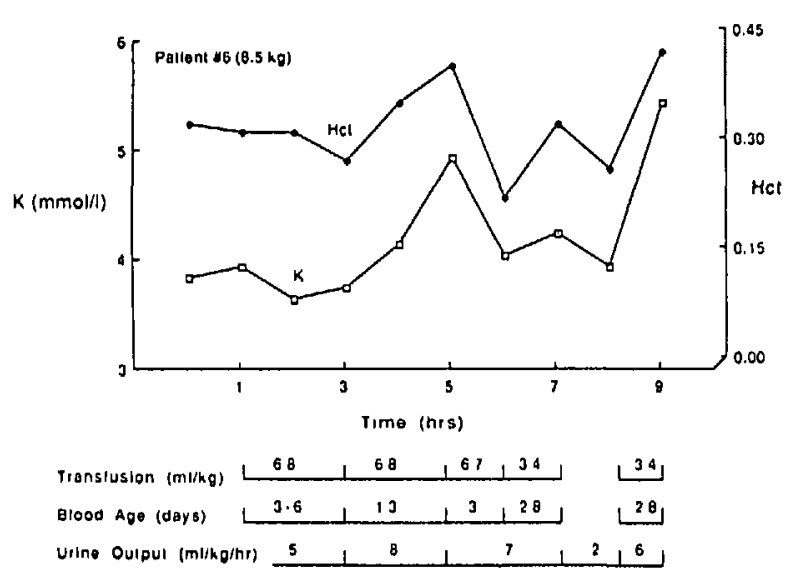

FIGURE 2 Representative patient showing the longitudinal trend of plasma $\left[\mathrm{K}^{+}\right]$and $\mathrm{Hct}$. The volume of $\mathrm{rWB}$ and the age of the units of RBCconc which were transfused were also presented.

shown in Figure 2. This patient experienced two increases in plasma $\left[\mathrm{K}^{+}\right]$. The first increase in plasma $\left[\mathrm{K}^{+}\right]$ occurred during the fourth hour of blood transfusion. The second occurred during the ninth hour. At the time of the first increase the age of the unit RBCconc being transfused was 13 days. The $K_{\text {dose }}$ at the time of the first increase in plasma $\left[\mathrm{K}^{+}\right]$was $1.34 \mathrm{mmol} \cdot \mathrm{kg}^{-1}$ delivered in $137 \mathrm{ml} \cdot \mathrm{kg}^{-1}$ of rWB over four hours. The second peak followed the transfusion of $34 \mathrm{mg} \cdot \mathrm{kg}^{-1}$ blood over one hour. The unit of $\mathrm{RBC}$ conc was 28 days old representing a $\mathrm{K}_{\text {dose }}$ of $0.63 \mathrm{mmol} \cdot \mathrm{kg}^{-1} \cdot \mathrm{hr}^{-1}$.

\section{Stored blood}

Twenty-eight units of RBCconc were analyzed. The $V_{R B C}$ ranged from $140-325 \mathrm{ml}$. The mean volume of

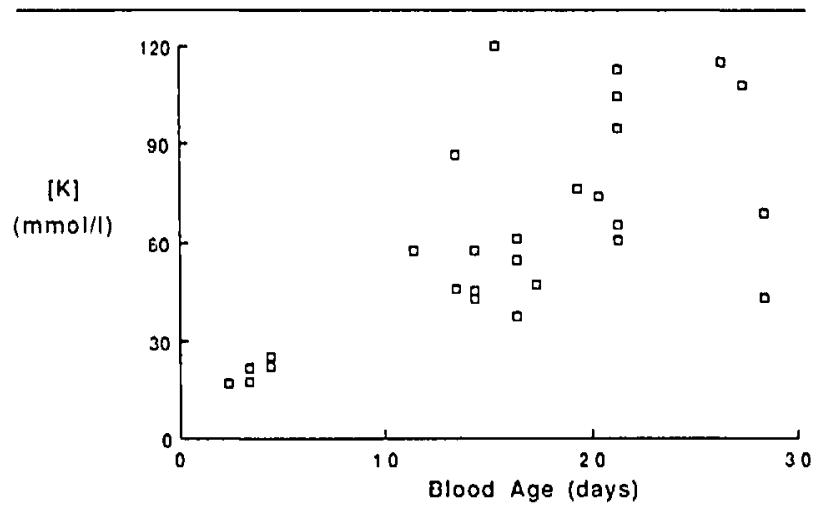

FIGURE 3 The relationship between storage time in days and the plasma $\left[\mathrm{K}^{+}\right]$of units of RBCconc.

RBCconc was $228 \pm 63 \mathrm{ml}$. The mean haematocrit was $0.73 \pm 0.10$. The mean plasma volume was $60.5 \pm 30.7$ $\mathrm{ml}$. The relationship between plasma $\left[\mathrm{K}^{+}\right]$and age of the blood is shown in Figure 3. Despite the small plasma volume, the units of RBCconc contained an extracellular potassium load of $1.4 \mathrm{mmol}$ at one week of age and $>3.7$ mmol at three weeks of age.

\section{Discussion}

Our results showed that during MCFS, children undergoing massive blood transfusion with units of RBCconc experienced a greater variability in plasma $\left[\mathrm{K}^{+}\right]$than the control group and a biochemically important increase in plasma $\left[\mathrm{K}^{+}\right]$. The mean age of children in the MCFS group was $3.1 \pm 3.2 \mathrm{yr}$ which is younger than the children in the control group. This supports the clinical impression that it was unusual for infants to undergo long surgical procedures which required invasive monitoring but did not require blood transfusion. There were no adverse biological sequelae of the acute increases in plasma $\left[\mathrm{K}^{+}\right]$, in particular no electrocardiographic changes were recorded. However, it should be pointed out that cardiac arrest was considered to be an exclusion criterion.

The longitudinal variability in intraoperative plasma $\left[\mathrm{K}^{+}\right]$in the ten MCFS patients was more than twice that of the control patients. There was a relationship between the acute increase in plasma $\left[\mathrm{K}^{+}\right]$and the trend in $\mathrm{Hct}$. Since the major factor increasing Hct intraoperatively was blood transfusion this correlation would suggest that blood transfusion was responsible for the increase in both $\mathrm{Hct}$ and plasma $\left[\mathrm{K}^{+}\right]$. However, blood transfusion was unlikely to have been the only factor influencing the plasma $\left[\mathrm{K}^{+}\right]$. For instance, patient \#8 showed a poor correlation between the Hct and blood transfusion. Other factors including changes in acid base status and fluctuation in the amount of tissue trauma might be expected to influence plasma $\left[\mathrm{K}^{+}\right]$during surgery. 
TABLE III

\begin{tabular}{|c|c|c|c|c|c|c|}
\hline \multirow[b]{2}{*}{ Patient } & \multicolumn{2}{|l|}{$p H$} & \multicolumn{2}{|c|}{$\mathrm{PCO}_{2}$ (lorr) } & \multicolumn{2}{|c|}{$\begin{array}{l}\text { Plasma }\left(K^{+}\right) \\
\left(\mathrm{mmol} \cdot \mathrm{L}^{-1}\right)\end{array}$} \\
\hline & Prepeak & Peak & Prepeak & Peak & Prepeak & Peak \\
\hline$\# 1$ & 7.37 & 7.42 & 33.0 & 36.0 & 4.5 & 6.7 \\
\hline \multirow[t]{2}{*}{$\# 2$} & 7.38 & 7.41 & 35.0 & 36.0 & 4.8 & 5.7 \\
\hline & 7.39 & 7.37 & 39.0 & 42.0 & 4.0 & 5.9 \\
\hline \#3 & 7.41 & 7.36 & 35.0 & 40.0 & 3.1 & 4.3 \\
\hline \#4 & 7.41 & 7.42 & 33.0 & 36.0 & 4.5 & 5.2 \\
\hline \#5 & 7.43 & 7.43 & 28.0 & 29.0 & 3.8 & 5.1 \\
\hline \multirow[t]{2}{*}{$\# 6$} & 7.38 & 7.35 & 31.0 & 44.0 & 3.6 & 4.9 \\
\hline & 7.48 & 7.29 & 35.0 & 57.0 & 3.9 & 5.4 \\
\hline \multirow[t]{2}{*}{$\# 7$} & 7.30 & 7.38 & 36.0 & 36.0 & 3.6 & 5.0 \\
\hline & 7.44 & 7.50 & 32.0 & 30.0 & 4.8 & 5.9 \\
\hline \multirow[t]{2}{*}{$\# 8$} & 7.47 & 7.49 & 31.0 & 30.0 & 3.8 & 5.1 \\
\hline & 7.49 & 7.50 & 32.0 & 29.0 & 4.7 & 5.6 \\
\hline \#9 & 7.34 & 7.33 & 37.0 & 40.0 & 4.8 & 6.0 \\
\hline$\# 10$ & 7.43 & 7.42 & 26.0 & 31.0 & 3.7 & 4.4 \\
\hline
\end{tabular}

Table outlines the acid base status ( $\mathrm{pH}$ and $\mathrm{PCO}_{2}$ ) in the ten patients who experienced an increase in plasma $\left[\mathrm{K}^{+}\right]$. Only patient \#6 had a decrease in $\mathrm{pH}$ at the time of an increase in plasma $\left[\mathrm{K}^{+}\right]$(See text).

Values for the arterial $\mathrm{pH}$ and $\mathrm{PCO}_{2}$ (Nova Biomedical Stat Profile 4 Analyzer) at the time of the increase in $\left[\mathrm{K}^{+}\right]$ are presented in Table III. The arterial $\mathrm{pH}$ preceding the peak in plasma $\left[\mathrm{K}^{+}\right]$is given for comparison. Only patient \#6 experienced a decrease in $\mathrm{pH}$ at the time of the increase in plasma $\left[\mathrm{K}^{+}\right]$. The remaining nine patients either had no change in arterial $\mathrm{pH}$ or an increase in $\mathrm{pH}$. The relationship between an acute change in acid base status has been the subject of recent investigation. It was once taught, as a rule of thumb, that a 0.1 change in $\mathrm{pH}$ units resulted in a reciprocal $0.6 \mathrm{mmol} \cdot \mathrm{L}^{-1}$ change in plasma $\left[\mathrm{K}^{+}\right]$. This seems to be true only for acute inorganic metabolic acidosis such as during $\mathrm{HCl}$ infusion. Acute organic metabolic acidosis and acute respiratory acidosis have been shown to cause minimal increase in plasma $\left[\mathrm{K}^{+}\right] \cdot{ }^{10-13} \mathrm{~A}$ change in acid base status cannot explain the increase in plasma $\left[\mathrm{K}^{+}\right]$seen in these patients.

Units of RBCconc aged two to five days had a plasma $\left[\mathrm{K}^{+}\right]$between 14 and $23 \mathrm{mmol} \cdot \mathrm{L}^{-1}$, while those $\geq$ two weeks of age had plasma $\left[\mathrm{K}^{+}\right]$ranging from $35-117$ $\mathrm{mmol} \cdot \mathrm{L}^{-1}$. These values of plasma $\left[\mathrm{K}^{+}\right]$are in agreement with the range of values reported in the literature. ${ }^{6-8}$

The increase on plasma $\left[\mathrm{K}^{+}\right]$is expected during storage as the erythrocytes lose potassium through the processes of haemolysis and diffusion. ${ }^{14-15}$ The energy-dependent membrane ionic pumps which maintain the transmembrane ionic gradients are inhibited during storage allowing potassium to diffuse out of erythrocytes. Since the whole blood donation is separated into its specific components very soon after donation, the erythrocytes in a unit of RBCconc have a near normal amount of intracel- lular (ICF) potassium. The ICF $\left.\left[\mathrm{K}^{+}\right]\left(\mathrm{RBC}^{+}\right]\right)$in erythrocytes is $100 \mathrm{mmol} \cdot \mathrm{L}^{-1}$ and the donor plasma $\left[\mathrm{K}^{+}\right]$is about $4 \mathrm{mmol} \cdot \mathrm{L}^{-1} .{ }^{16}$ Therefore a considerable concentration gradient for diffusion of potassium from cells exists. The plasma [ $\mathrm{K}^{+}$] seemed to plateau after 20 days of storage. This tendency to plateau was supported by the spread of data points in the papers by Michael $^{7}$ and Degowin. ${ }^{14} \mathrm{~A}$ plateau in the plasma $\left[\mathrm{K}^{+}\right]$implies a limit to the value that the plasma $\left[\mathrm{K}^{+}\right]$may rise during storage. If the RBC and plasma volumes are assumed to remain constant then the concentration equilibrium between the intracellular (ICF) and plasma compartments can be determined.

Given that a donor unit of $450 \mathrm{ml}$ of whole blood, with $63 \mathrm{ml}$ of CPDA-1 preservative, has a Hct of about 0.45 , the total unit contains $210 \mathrm{ml}$ of erythrocytes and $21 \mathrm{mmol}$ of intracellular potassium. This volume of erythrocytes can be stored either as a unit of whole blood (PV $=290$ $\mathrm{ml}$ ) or RBCconc (Hct $0.7, \mathrm{PV}=90 \mathrm{ml}$ ). The potassium which diffuses out of the donor erythrocytes $(\mathrm{Kdec})$ into the plasma fraction of the unit of blood will increase the plasma $\left[\mathrm{K}^{+}\right]$such that:

Plasma $\left[\mathrm{K}^{+}\right]=\frac{((\mathrm{Ko} \cdot \mathrm{PV})+\mathrm{Kdec})}{\mathrm{PV}}$

where $K_{0}$, the initial plasma $\left[\mathrm{K}^{+}\right]$, is assumed to be 4 $\mathrm{mmol} \cdot \mathrm{L}^{-1}$ and $\mathrm{PV}$ is the plasma volume of the unit of blood. Diffusion of potassium from cells would decrease the $\mathrm{RBC}\left[\mathrm{K}^{+}\right]$such that:

$$
\begin{aligned}
\mathrm{RBC}\left[\mathrm{K}^{+}\right] & =\frac{\left(\left(100 \mathrm{mmol} \cdot \mathrm{L}^{-1} \cdot 210 \mathrm{cc}\right)-\mathrm{Kdec}\right)}{210 \mathrm{cc}} \\
& =\frac{(21 \mathrm{mmol}-\mathrm{Kdec})}{210 \mathrm{cc}}
\end{aligned}
$$

Potassium will continue cells by diffusion until the intracellular and extracellular $\left[\mathrm{K}^{+}\right]$are in concentration such that:

$$
\begin{aligned}
\text { plasma }\left[\mathrm{K}^{+}\right] & =\mathrm{RBC}\left[\mathrm{K}^{+}\right] \\
\frac{(\mathrm{Ko} \cdot \mathrm{PV})+\mathrm{Kdec})}{\mathrm{PV}} & =\frac{(21 \mathrm{mmol}-\mathrm{Kdec})}{210 \mathrm{cc}}
\end{aligned}
$$

Figure 4 shows that if the $210 \mathrm{ml}$ of donor erythrocytes were stored as RBCconc $(\mathrm{Hct}=0.7, \mathrm{PV}=90 \mathrm{ml}$ ), a concentration equilibrium between the ICF and plasma $\left[\mathrm{K}^{+}\right]$is reached at about $70 \mathrm{mmol} \cdot \mathrm{L}^{-1}$ when roughly 30 per cent of the intracellular RBC potassium has diffused from the cells. In contrast, if the $210 \mathrm{ml}$ of donor erythrocytes were stored as whole blood $(\mathrm{Hct}=0.4$, PV $=290 \mathrm{ml}$ ), the concentration equilibrium would occur at $45 \mathrm{mmol} \cdot \mathrm{L}^{-1}$, when the RBCs have lost about half of their intracellular potassium. It is curious that the diffu- 


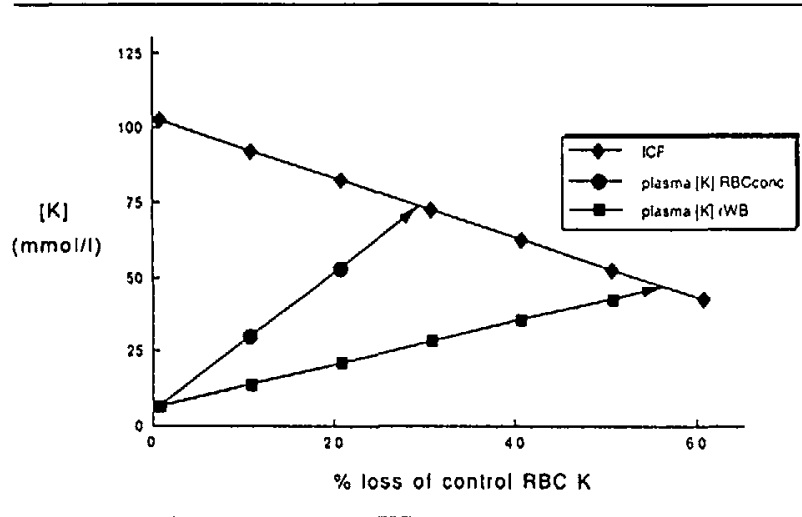

FIGURE 4 The plasma $\left[\mathrm{K}^{+}\right]$plotted against per cent decrease in intracellular potassium content for $210 \mathrm{ml}$ of donor erythrocytes representing $21 \mathrm{mmol}$ of intracellular potassium, when stored either as RBCconc (Hct 0.7, PV $290 \mathrm{ml}$ ) or as whole blood (Hct 0.4, PV 90 $\mathrm{ml})$. Concentration equilibrium in the unit of RBCconc occurs at 70 $\mathrm{mmol} \cdot \mathrm{L}^{-1}$ when about one-third of the intracellular potassium has diffused from the donor erythrocytes. Concentration equilibrium in the unit of whole blood occurs at $45 \mathrm{mmol} \cdot \mathrm{L}^{-1}$ when about half of the intracellular potassium has diffused out of the donor erythrocytes (See text)

sion of potassium from erythrocytes during storage appears to occur slowly over several weeks because the $\mathrm{Na}^{+}-\mathrm{K}^{+}$ATPase probably fails within days following blood donation. It may imply that not all of the intracellular potassium is in a readily exchangeable pool.

It is evident that storage time is an important factor influencing the amount of extracellular potassium in a unit of RBCconc. ${ }^{6-8,14-16}$ However, Figure 3 shows that even units of similar storage age have a wide variability in plasma $\left[\mathrm{K}^{+}\right]$with a coefficient of variation of approximately 25 per cent. The variation in haematocrit can explain some of this variability. For instance, if the 210 $\mathrm{ml}$ of erythrocytes are stored in plasma such that the haematocrit is 0.6 , then a $4.2 \mathrm{mmol}$ decrement in intracellular potassium will result in a plasma $\left[\mathrm{K}^{+}\right]$of 34 $\mathrm{mmol} \cdot \mathrm{L}^{-1}$. Whereas if this same volume of erythrocytes is stored with a haematocrit of 0.8 , then a $4.2 \mathrm{mmol}$ decrement will result in a plasma $\left[\mathrm{K}^{+}\right]$of $84 \mathrm{mmol} \cdot \mathrm{L}^{-1}$. Figure 5 shows the relationship between $\mathrm{Hct}$ and plasma $\left[\mathrm{K}^{+}\right]$for the eight units of $\mathrm{RBCconc} \geq 21$ days of age. The relationship is well described by simple linear regression $\left(y=-93.5+232.54 x, r^{2}=0.89\right)$.

Five units of RBCconc had a plasma $\left[\mathrm{K}^{+}\right]$in excess of $100 \mathrm{mmol} \cdot \mathrm{L}^{-1}$ (Figure 3). This may imply that other processes besides diffusion cause potassium to be released into the plasma fraction. During storage erythrocytes lose intracellular anions. This may result in a less negative intracellular charge relative to the plasma fraction. This would create an electrical gradient between the intracellular and plasma compartments which could repel potassium from the intracellular space. ${ }^{17}$

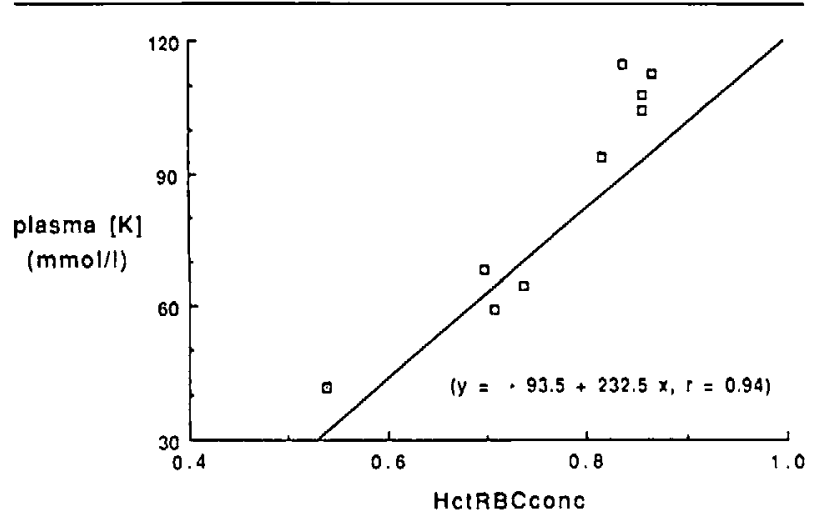

FIGURE 5 The relationship between plasma $\left|\mathrm{K}^{+}\right|$and $\mathrm{Hct}$ in the eight units of RBCconc > three weeks of age

Transfusion of RBCconc delivers an obligatory intravenous potassium load. The magnitude of the potassium load depends on (1) the age of the unit of RBCconc, (2) its plasma volume and (3) its plasma $\left[\mathrm{K}^{+}\right]$. Following transfusion, erythrocytes are expected to recover their intracellular potassium. However, full recovery requires several days. ${ }^{16,17}$ Valerie et al. ${ }^{17}$ showed this in an elegant study which involved the transfusion of type $O$ donor erythrocytes into non-O recipients. The time course of recovery of the transfused red blood cell intracellular potassium was followed for two weeks. The intracellular potassium content of the stored erythrocytes was decreased 20-30 per cent from the control value. There was minimal recovery of intracellular potassium at eight hours post-transfusion and a slight increase at $24 \mathrm{hr}$ posttransfusion. Full recovery of intracellular potassium in the donor erythrocytes required upwards of one week. Therefore the free potassium contained in the plasma portion of transfused blood must be disposed of as if it were an exogenous potassium load.

Massive blood loss in these children was replaced with reconstituted whole blood (rWB). This was prepared by suspending a unit of RBCconc in a unit of plasma prior to transfusion. From the anaesthetic records the transfusion rate of rWB given to each patient and the age of the unit of RBCconc which had been used in the unit of rWB were known. To assess the amount of free potassium delivered with the blood transfusion, it was necessary to estimate the amount of extracellular potassium delivered per unit

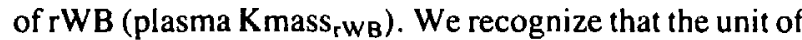
plasma used to suspend the unit of RBCconc must also have contained potassium. However, the plasma $\left[\mathrm{K}^{+}\right]$, in units of stored plasma, has been measured at about 5 $\mathrm{mmol} \cdot \mathrm{L}^{-1}$ (unpublished observations) and therefore was assumed to be negligible. Four patients received a $\mathrm{K}_{\text {dose }}<$ $0.3 \mathrm{mmol} \cdot \mathrm{kg}^{-1} \cdot \mathrm{hr}^{-1}$.

It is curious that this small $\mathrm{K}_{\text {dose }}$ was associated with a 
TABLE IV

\begin{tabular}{rlllllr}
\hline Patient & $\begin{array}{l}\text { Time } \\
(\mathrm{hrs})\end{array}$ & $\begin{array}{l}K_{\text {laad }} \\
\left(\mathrm{mmol} \cdot \mathrm{kg}^{-1} \cdot \mathrm{hr}^{-1}\right)\end{array}$ & $\begin{array}{l}\left(\mathrm{K}^{+}\right) \\
\left(\mathrm{mmol} \cdot \mathrm{L}^{-1}\right)\end{array}$ & $\begin{array}{l}K_{p} \\
\left(\mathrm{mmol} \cdot \mathrm{L}^{-1}\right)\end{array}$ & $\begin{array}{l}K_{o} \\
\left(\mathrm{mmol} \cdot \mathrm{L}^{-1}\right)\end{array}$ & \%Exit \\
\hline 7 & 1 & 0.80 & 5.0 & 8.0 & 1.4 & 82.5 \\
4 & 1 & 0.64 & 5.2 & 3.2 & 0.7 & 78.0 \\
9 & 1 & 1.23 & 6.0 & 6.2 & 1.4 & 77.2 \\
1 & 1 & 1.06 & 6.7 & 5.3 & 2.1 & 60.4 \\
6 & 1 & 0.63 & 5.4 & 3.2 & 1.5 & 53.0 \\
10 & 2 & 0.21 & 4.4 & 2.1 & 1.2 & 44.0 \\
5 & 2 & 0.29 & 5.1 & 2.9 & 1.9 & 34.0 \\
2 & 1 & 0.25 & 5.9 & 1.2 & 0.9 & 27.0 \\
3 & 1 & 0.21 & 4.4 & 1.1 & 1.3 & -18.2 \\
\hline
\end{tabular}

The $\mathrm{K}_{\text {dose }}, \mathrm{K}_{\mathrm{p}}, \mathrm{K}_{0}$ and per cent Exit for the nine patients demonstrating an acute increase in plasma $\left[\mathrm{K}^{+}\right]$during blood transfusion of a significant amount of blood over a period of two hours. Patients are listed in order of descending value for per cent Exit. The plasma $\left[\mathrm{K}^{+}\right]$is also given.

significant increase in plasma $\left[\mathrm{K}^{+}\right]$. One explanation may be an inaccuracy in the methodology because the units of $\mathrm{RBCconc}$ were grouped according to age by week and a mean value was used for determining the $\mathrm{K}_{\text {dose }}$. If a patient received a unit of RBCconc containing a high $\mathrm{K}$ load, then the mean value used to estimate the $K_{\text {dose }}$ would have underestimated the actual dose. A second explanation may be the physiological response to a potassium challenge. The immediate response to an increase in plasma $\left[\mathrm{K}^{+}\right]$is predominantly extrarenal and consists of (1) redistribution of potassium within the extracellular space and (2) translocation of potassium into the intracellular space. ${ }^{18-21}$

Redistribution and dilution of potassium are important to the maintenance of a normal plasma $\left[\mathrm{K}^{+}\right]$. Certainly there is a time requirement for a potassium load to circulate and distribute within the ECF and to shift into the ICF. Rapid bolus transfusion, particularly into an hypotensive hypovolaemic circulation, may give rise to important mixing inhomogeneities in plasma $\left[\mathrm{K}^{+}\right] .{ }^{22,23}$ However, our review did not document any significant episodes of hypotension. It is unlikely that important mixing inhomogeneities of potassium concentration were present in these patients.

The ability to translocate potassium intracellularly can be estimated if one assumes that the difference between the observed change in plasma $\left[\mathrm{K}^{+}\right]\left(\mathrm{K}_{\mathrm{o}}\right)$ and the predicted one $\left(\mathrm{K}_{\mathrm{p}}\right)$ was due to the amount of potassium which is removed from the ECF: ${ }^{21}$

$\%$ Exit $=100 \times\left(1-\frac{\mathrm{Ko}}{\mathrm{Kp}}\right)$

where

$\mathrm{Kp}=\frac{\mathrm{K}_{\mathrm{dose}}}{\mathrm{ECF}}$

and ECF is assumed to equal to $200 \mathrm{ml} \cdot \mathrm{kg}^{-1}$.
Table IV gives the values for per cent Exit in nine patients in descending order of per cent Exit. In addition the $\mathrm{K}_{\text {dose }}$ and plasma $\left[\mathrm{K}^{+}\right]$at the time of the potassium spike are given. Four of the nine patients had a per cent Exit of $<50$ per cent, which may indicate an impairment in the ability to translocate potassium into cells. One might speculate that during anaesthesia, the movement of potassium across cell membranes is altered because several factors, which influence this ion flux, namely (1) anaesthetic drugs, (2) hormonal milieu, (3) acid-base status, (4) metabolic rate and (5) previous potassium intake, may be influenced perioperatively. ${ }^{24-31}$

\section{Acknowledgements}

We would like to acknowledge, with gratitude, the technical expertise of the staff of the Departments of Hematology/Blood Bank and Biochemistry, The Hospital for Sick Children. We also thank Dr. M. Halperin, Renal Division, St. Michael's Hospital, for his encouragement and help in reviewing this manuscript. We also appreciate the efforts of Ms. T. Cain in the preparation of this manuscript.

\section{References}

1 Scanlon JW, Krakaur $R$. Hyperkalemia following exchange transfusion. J Pediatr 1980; 96: 108-10.

2 Mollison PL. Blood Transfusion in Clinical Medicine. 4th ed. Oxford: Blackwell Scientific Publications, 1967, 628-32.

3 Côté CJ. Blood replacement and blood product management. In: A Practice of Anesthesia for Infants and Children. Ryan JF, Todres ID, Côté CJ, Goudsouzian NG (Eds.). Orlando: Grune \& Stratton Inc., 1986, 123-32.

4 Marshall $M$. Potassium intoxication from blood and plasma transfusions. Anaesthesia 1962; 17: 145-7.

5 Miller RD, Brzica SM. Blood, blood components, colloids and autotransfusion therapy. In: Anesthesia. Miller RD 
(Ed.). 2nd edition. New York: Churchill Livingston, 1986, 1329-36.

6 Moore GL, Peck CG, Sohmer PR, Zuck TF. Some properties of blood stored in CPDA-I solution. Transfusion 1981; 21: 135-8.

7 Michael JM, Dorner I, Bruns D, Ladenson JH, Sherman $L A$. Potassium load in CPD-preserved whole blood and two types of packed red blood cells. Transfusion 1975; 15 : 144-9.

8 Simon GE, Bove JR. The potassium load from blood transfusion. Postgrad Med 1971; 49: 61-4.

$9 \mathrm{Zar} J H$. Biostatistical Analysis. 2nd edition. Englewood Cliffs: Prentice-Hall Inc., 1984.

10 Peterson BD, Jackson JA, Buckley JJ, van Bergen $\mathrm{FH}$. Influence of alterations in arterial blood $\mathrm{pH}$ and carbon dioxide tension on plasma potassium levels in humans anesthetized with nitrous oxide, thiopental and succinylcholine. J Appl Physiol 1957; 11: 93-6.

11 Halperin $M L$, Bear R, Goldstein MB, Richardson RMA, Robson WLM. Interpretation of the serum potassium concentration in metabolic acidosis. J Clin Invest Med 1979; 2: 55-7.

12 Magner PO, Robinson L, Halperin RM, Zettle R, Halperin $M L$. The plasma potassium concentration in metabolic acidosis: a re-evaluation. Am J Kid Dis 1989; 3: 220-4.

13 Adroqué HJ, Madias NE. Changes in plasma potassium concentration during acute acid-base disturbance. Am J Med 1981; 71: 456-7.

14 DeGowin EL, Harris JE, Plass ED. Studies on preserved human blood. II. Diffusion of potassium from the erythrocytes during storage. JAMA 1940; 114: 855-7.

15 Latham JT, Bove JR, Weirich FL. Chemical and hematologic changes in stored CPDA- 1 blood. Transfusion 1982; 22: 159-62.

16 Mollison PL. Blood Transfusion in Clinical Medicine. 4th ed. Oxford: Blackwell Scientific Publications, 1967. 71-2.

17 Valerie $C R$, Hirsch NM. Restoration in vivo of erythrocyte adenosine triphosphate, 2,3-diphosphoglycerate, potassium ion, and sodium ion concentrations following the transfusion of acid-citrale-dextrose-stored human red blood cells. J Lab Clin Med 1969; 73: 722-32.

18 Halperin $M$, Goldstein $M$. Fluid, Electrolyte, and AcidBase Emergencies. Toronto: W.B. Saunders Co., 1988, 209-68.

19 DeFronzo RA, Taufield PA, Black H, McPhedran P, Cooke $R$. Impaired renal tubular potassium secretion in sickle cell disease. Ann Int Med 1979; 90: 310-6.

20 Blachley JD, Crider BP, Johnson JH. Extrarenal potassium adaptation: role of skeletal muscle. Am J Physiol 1986; 20: F313-8.
21 Sterns RH, Feig PU, Pring M, Guzzo J, Singer I. Disposition of intravenous potassium in anuric man: a kinetic analysis. Kidney Int 1979; 15: 65I-60.

22 Brown KA, Bissonnette B, Mclntyre B. Hyperkalemia during cardiac arrest in the pediatric patient. Anesthesiology 1989; 7I: A 1014.

23 Brown K, Bissonnette B, Mclntyre B. Model analysis of left ventricular $\left[\mathrm{K}^{+}\right]$during massive blood transfusion in children. Can J Anaesth 1989; 36: S100.

24 Lindahl SGE. Energy expenditure and fluid and electrolyte requirements in anesthetized infants and children. Anesthesiology 1988; 69: 377-82.

25 Brown RS. Extrarenal potassium homeostasis. Kidney Int 1986; 30: 116-27.

26 Sterns RH, Cox M, Feig PU, Singer I. Internal potassium balance and the control of the plasma potassium concentration. Medicine 1981; 60: 339-54.

27 Horberer $F F$, Krayer $S$, Rehder $K$, Haymond MW. Anesthesia with halothane and nitrous oxide alters protein and amino acid metabolism in dogs. Anesthesiology 1988; 69: $318-26$.

28 Barchfeld $G L$, Deamer DW. The effect of general anesthetics on the proton and potassium permeabilities of liposomes. Biochim Biophys Acta 1985; 819: 161-9.

29 DeFronzo RA, Sherwin RS, Sillingham $M$, Hendler $R$, Tamborlane $W V$, Felig $P$. Influence of basal insulin and glucagon secretion on potassium and sodium metabolism. J Clin Invest 1978; 61: 472-9.

30 Wong KC, Wetsone $D$, Martin D, Cheney $F$, White $S R$. Hypokalemia during anesthesia: the effects of d-tubocurarine, gallamine, succinylcholine, thiopental, and halothane with or without respiratory alkalosis. Anesth Analg 1973; 52: 522-8.

31 Gronet GA, Theye RA. Pathophysiology of hyperkalaemia induced by succinylcholine. Anesthesiology 1975; 43: 89-99. 